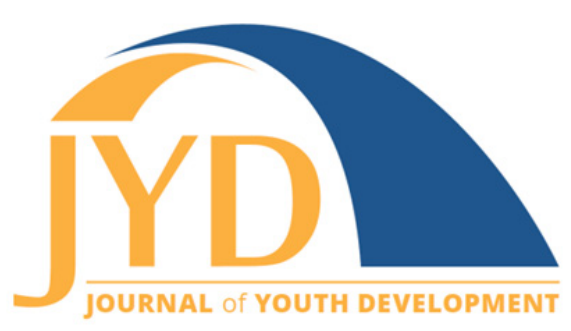

http://jyd.pitt.edu/ | Vol. 12 Issue 3 DOI 10.5195/jyd.2017.451 | ISSN 2325-4017 (online)

\title{
BLAST: A Promising Approach to Service, Ethics, and Leadership Development in Rural Canada
}

Zia Saleh

Oxford University

University of Alberta

zia.saleh@gmail.com

Vance Nakonechny

St. Mary School

vnakonechny@ecsrd.ca

Maurice St. Denis

R. F. Staples Secondary School

Maurice.st.denis@phrd.ab.ca

Darren Nichols

University of Alberta

dnichols@ualberta.ca

\begin{abstract}
As youth define their identity and the values by which they live their lives, formative programs have the potential to change their life trajectories in productive ways. This study aimed to investigate the impact of a rural youth development program that focused on service, ethics, and leadership. In this program, nine rural students (aged 13-18) initiated and led community service projects, engaged in educational sessions on ethics and character development, and formed a diverse social support network. Survey data and a thematic focus group analysis revealed that the program resulted in: (a) skill-building in the areas of teamwork, planning and life management, social interaction, and self-confidence; (b) increased interest and confidence in initiating service projects; (c) development of leadership skills; (d) maturation of personal ethical foundations; and (e) an appreciation of pluralism through working with others in the community. Potential improvements to the model were also uncovered through this process.
\end{abstract}

Key words: service learning, ethics, leadership, youth development, rural

(cc) EY New articles in this journal are licensed under a Creative Commons Attribution 4.0 License. This journal is published by the University Library System, University of Pittsburgh and is cosponsored by the University of Pittsburgh Press. The Journal of Youth Development is the official peer-reviewed publication of the National Association of Extension 4-H Agents and the National AfterSchool Association. 


\section{Introduction}

Positive development during adolescence is an opportunity to shape one's future trajectory in life. As youth attempt to balance an internal identity with external forces of influence, they simultaneously curate the value foundations and mental frameworks upon which they make life decisions.

It is in this moment that youth development interventions can contribute value (Catalano, Berglund, Ryan, Lonczak, \& Hawkins, 2004). Efforts can be targeted toward a multitude of areas that influence one's developmental trajectory, such as education system design, career development, social networks, peer influence, familial dynamics, religious influence, or other biopsychosocial contributing areas. An alternative approach to area-based influence is to focus on developing assets in youth that can impact their lives across numerous areas. These assets-consisting of skills, ideas, and competencies-have been shown to shape future life significantly by contributing to one's academic, behavioural, psychological, and social success (Scales et al., 2015; Search Institute, 2012). The literature to date has demonstrated how asset development can promote thriving behaviours (such as academic engagement, leadership, and a desire to serve others) while limiting the likelihood of harmful activities (such as early sexual activity, violence, suicide, and drug use) (Scales et al., 2015; Search Institute, 2012). Moreover, these assets are seen to work synergistically to promote one's confidence, competence, connection, character, and compassion allowing youth to contribute to their family, community, and society (Zaff, Lerner, \& Richard, 2010).

While the utility of quality asset-focused development initiatives is clear, strategies to promote such practices are diverse and growing. Among others, three particular areas of asset development appear to have useful effects: service, leadership, and ethical development (Zaff et al, 2010). Service learning has been shown to help students develop civic motivation, skills, and commitment (Zaff et al, 2010). Fostering leadership among youth can contribute to one's skills in decision-making, goal-setting, teamwork, and community service (Edelman, Gill, Comerford, Larson, \& Hare, 2004). Ethics development, though perceived to be unquestionably important by many, has not been heavily investigated as an explicitly taught skill but has made some headway in the areas of social-emotional learning and sport-based education (Devaney, O'Brien, Tavegia, \& Resnik, 2005; Devaney et al, 2005; Harvey, Kirk, \& O’Donovan, 2014). Though service learning, leadership, and ethical development have been investigated primarily as individual or dual entities, youth development models that explicitly combine the three asset areas are scarce. This scarcity is particularly acute in rural contexts. Though the literature on 
BLAST: A Service, Ethics, and Leadership Approach

rural youth development has documented successes in service learning, social capital building, leadership, and civic engagement through programs such as 4- $\mathrm{H}$ and Future Farmers of America (FFA), a study on a synergistic model explicitly combining service, leadership, and ethical development has not yet been documented in a rural context (Andresen, Dallpiazza, \& Calvert, 2013; Hastings, Barrett, Barbuto, \& Bell, 2011; Henness, Ball, \& Moncheski, 2013; Ludden, 2011).

This study contributes to the literature in two areas. First, it aims to uncover what can be learned from a synergistic youth development model integrating service learning, leadership, and ethical development and its impact on youth. Second, it seeks to demonstrate the model's performance in a rural-based Canadian context.

\section{Methods}

\section{Program Development}

Developed through a partnership between researchers and two staff members of participating local schools, the ten-month BLAST (Building Leaders Around Successful Thinking) program exposed youth to the tenets of service, ethics, and leadership. The model (Figure 1) was developed and executed in five stages: planning and vision development, student recruitment, meetings and social events, evaluation (through surveys and focus groups), and sustainability planning. The first stage was a month-long process dedicated to stakeholder discussions on the development of a common and relevant vision, the structure of the program, and a plan for its core components. Stakeholders at this stage primarily included program visionaries, given students had not yet been recruited; however, students were able to give feedback and contribute to this process in their first program meeting. The second stage involved student recruitment, which primarily occurred through a process of flyer-based advertising along with targeted staff encouragement to potentially interested students. Once students were enrolled, the third phase of the program began involving further refinement of the program's vision and structure based on student input. Students also came up with a name for the program (BLAST). Thereafter, meetings took place over the course of the year during school hours at times convenient for students and faculty. Staff permission for class attendance exemption was required provided that students would cover missed material on their own time. Meetings consisted of lectures, discussions, and service-based work. Social bonding was also planned through out-of-school activities. The fourth phase of the project consisted of surveys and focus groups to evaluate the project. The fifth and final phase consisted of a meeting specifically 
centred around the students' plan for how to keep the program sustainable and student-led in the years ahead.

Figure 1. Program Model-BLAST (Building Leaders Around Successful Thinking)

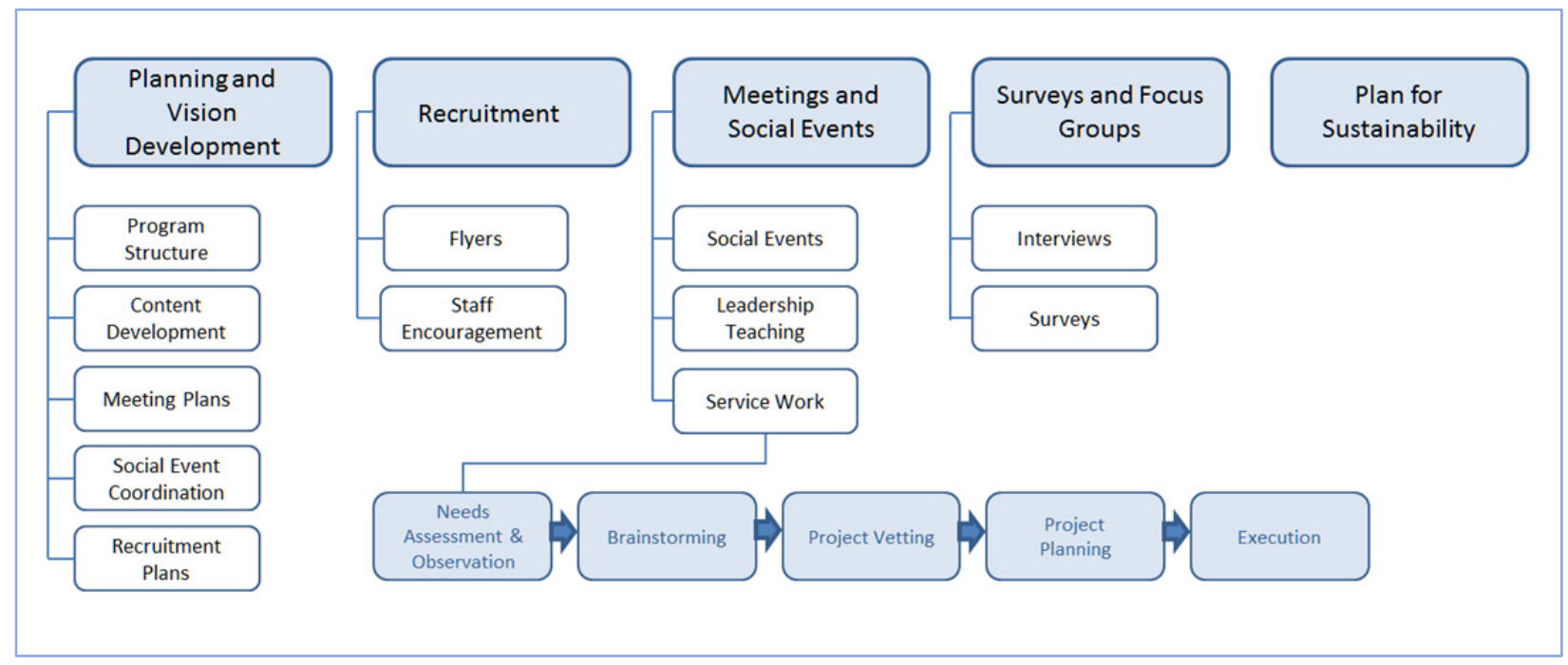

\section{Program Content}

The program delivered content in three main areas:

- Leadership and ethics-based teaching/discussions. Sessions focused on the following concepts: cultivating a desire to engage in service to humanity, encouraging a willingness to take risks in leadership, and appreciating pluralism and diversity in our world through a cosmopolitan ethic. To promote student leadership, students also had the opportunity to lead teaching sessions on topics they felt passionate about over the course of the year.

- Community service projects. After an initial presentation on the nature of service and common pitfalls, students conducted a needs and strengths assessment of their communities. They then went on to brainstorm potential project ideas based on this assessment that were mapped against criteria that predicted project success (e.g. sustainability, affordability, relevance, bidirectionality). After the students decided upon the two most feasible projects, they assigned themselves to the projects based on their interest. Project planning and execution followed this step. The projects that were implemented were a community mental health awareness night (a speaker, student presentation, and the showing of the movie Inside Out) and a senior companionship project consisting of sessions with the local long-term care residents involving 
BLAST: A Service, Ethics, and Leadership Approach

reminiscing, student concerts, and games. The program ended with a discussion around a sustainability model for the entire BLAST program and students set up a plan for the years ahead.

- Social interaction. Social interaction occurred through regular meetings, student-led meetings with project partners, and structured events such as a board game and dinner night. This interaction was unique in its effort to create collaboration between two schools that often functioned independently within the same community.

\section{Program Resources}

The overall cost of the program was less than $\$ 100$ CAD. Facilities were provided by the school and program leader time was offered freely and voluntarily. The main costs incurred by the program were those associated with the social event along with peripheral costs associated with meetings (printouts, foodstuffs). Service event-associated costs were donated by the community (e.g. venue, popcorn, and water for the mental health awareness night).

\section{Participants}

Our sample consisted of students in Westlock, Alberta, Canada ( $n=9$, ages $13-18,33 \%$ male, $66 \%$ female).

\section{Ethics}

The Research Ethics Board at the University of Alberta approved the survey and focus group study that assessed program impact. All participating students gave written consent.

\section{Evaluation Design}

A mixed-methods design was used to evaluate the program drawing information from surveybased responses and focus group data. The details of each are below.

Focus Groups. The nine students were interviewed in a classroom-based setting in two focus groups, the first with six students and the second with three. Students were informed prior to the interviews that their interviews would be tape-recorded. A sole group facilitator presented the questions as per the protocol in a guided manner. Interviews lasted between 20-28 minutes. 
BLAST: A Service, Ethics, and Leadership Approach

Surveys. After participating in a focus group discussion, the students were given a thirteen-item survey (ten Likert-based, three open-ended) to complete on an individual basis. Data was gathered from all full-year participants.

Analysis Method. Focus group discussions were transcribed by the sole facilitator and were assessed on a line-by-line basis to identify emerging themes, which were then were recorded in Microsoft Office Word and Excel. Next, the transcripts were reviewed a second time and the presence of themes was tabulated for each student. This led to a broader understanding of how many students referred to a theme at least once in the interview.

Mean, median, and standard deviation were calculated for the Likert-based responses to delineate the general impact of the program and its spread on key objectives. The open-ended survey questions were scanned for recurring themes and response-type frequency. These were recorded by theme and assigned a frequency percentage. They were then compared to focus group themes to assess for overlap.

\section{Results}

Ten students started the year and nine completed the BLAST program. It is unknown why one student left the program. All nine students who completed the year participated in survey and focus groups. Survey responses demonstrated that the program had a beneficial impact on students in the realms of service, leadership, and ethical development as well as in the expansion of social networks. This is exemplified by the fact that the majority of students agreed with the statements in all tested categories, as seen in Table 1. Of important note is that no student gave a response of less than 3 for any item. In other words, no student disagreed with any of the statements. The consensus around agreement is strongest in the category of leadership, where $100 \%$ of students either agreed or strongly agreed. In the service category, $93 \%$ of responses suggested agreement or strong agreement. The weakest results were in the ethical decision-making category where only $72 \%$ of responses suggested agreement or strong agreement. 
Journal of Youth Development | http://jyd.pitt.edu/ | Vol. 12 Issue 3 DOI 10.5195/jyd.2017.451 BLAST: A Service, Ethics, and Leadership Approach

\section{Themes from Likert-Based Survey Questions}

Table 1. Survey Questions and Response Mean, Median, and Standard Deviation

\begin{tabular}{|c|c|c|c|}
\hline $\begin{array}{c}\text { Survey Questions } \\
\text { Pre-question prompt: Please indicate your response to the following } \\
\text { statements. Each rated on a scale of } 1 \text { to } 5.1=\text { strongly disagree, } 2 \text { = } \\
\text { disagree, } 3=\text { neutral, } 4=\text { agree, } 5=\text { strongly agree. }\end{array}$ & $\begin{array}{l}\text { Mean } \\
\text { Score }\end{array}$ & SD & $\begin{array}{l}\text { Median } \\
\text { Score }\end{array}$ \\
\hline \multicolumn{4}{|l|}{ Service } \\
\hline $\begin{array}{l}\text { 1. The program strongly increased my interest in acts of service to } \\
\text { humanity. }\end{array}$ & 4.44 & 0.73 & 5.00 \\
\hline $\begin{array}{l}\text { 2. The program improved my ability to analyze service projects in a critical } \\
\text { manner. }\end{array}$ & 4.11 & 0.60 & 4.00 \\
\hline 3. The program gave me an opportunity to explore service in a new way. & 4.44 & 0.53 & 4.00 \\
\hline \multicolumn{4}{|l|}{ Leadership } \\
\hline 1. The program has helped me improve my leadership skills. & 4.33 & 0.50 & 4.00 \\
\hline 2. The program has improved my ability to work in a group setting. & 4.78 & 0.43 & 5.00 \\
\hline $\begin{array}{l}\text { 3. The program has increased my confidence and willingness to take } \\
\text { meaningful risks. }\end{array}$ & 4.44 & 0.53 & 4.00 \\
\hline \multicolumn{4}{|l|}{ Ethical Decision-Making } \\
\hline $\begin{array}{l}\text { 1. The program has exposed me to certain ethical principles that I now } \\
\text { value. }\end{array}$ & 4.44 & 0.99 & 4.00 \\
\hline $\begin{array}{l}\text { 2. The program has challenged me to think about the ethical principles that } \\
\text { direct my actions. }\end{array}$ & 4.33 & 0.79 & 4.00 \\
\hline \multicolumn{4}{|l|}{ Other } \\
\hline $\begin{array}{l}\text { 1. Going through the program has helped me make new friends and } \\
\text { expanded my social network. }\end{array}$ & 4.67 & 0.71 & 5 \\
\hline
\end{tabular}

\section{Themes from Open-Ended Survey Questions and Focus Groups}

Responses to open-ended survey questions (Table 2) and themes from focus groups (Table 3) demonstrated significant overlap. It is clear that the main benefits of the program are related to social skill development, service learning, time and life management experience, teamwork and leadership development, ethical exploration, and learning to be open-minded. 
BLAST: A Service, Ethics, and Leadership Approach

Improvements to the program were primarily focused on meeting scheduling and timing (a constant challenge given that the program occurred during school hours, which was a request of the staff) and increasing the awareness of the program to target and recruit more students. Other suggestions included improving communication and organization and having more social events.

\section{Table 2: Open-Ended Survey Question Responses and their Frequencies}

\begin{tabular}{|c|c|}
\hline Questions & Responses and Their Frequency \\
\hline $\begin{array}{l}\text { What are the three most } \\
\text { important things you gained } \\
\text { from this program? }\end{array}$ & $\begin{array}{l}\text { - Social skills (44\%) } \\
\text { - Teamwork skills }(44 \%) \\
\text { - Planning skills }(33 \%) \\
\text { - Risk-taking ( } 33 \%) \\
\text { - Open-mindedness (33\%) } \\
\text { - Leadership ( } 22 \%) \\
\text { - Confidence }(22 \%) \\
\text { - Learning to make change }(11 \%) \\
\text { - Ethical views }(11 \%) \\
\text { - Learning personal boundaries }(11 \%)\end{array}$ \\
\hline $\begin{array}{l}\text { How can we improve the } \\
\text { program? }\end{array}$ & $\begin{array}{l}\text { - Meeting scheduling/timing (67\%) } \\
\text { - Increase age/size/diversity of group (33\%) } \\
\text { - Increase communication between members (22\%) } \\
\text { - Improve organization/structure }(22 \%) \\
\text { - Increase number of social events ( } 22 \%) \\
\text { - Spread awareness (11\%) }\end{array}$ \\
\hline Anything else? & $\begin{array}{l}\text { Most comments in this section were messages of gratitude and } \\
\text { affirmations of enjoyment. }\end{array}$ \\
\hline
\end{tabular}


BLAST: A Service, Ethics, and Leadership Approach

Table 3: Focus Group Discussion Themes, Their Frequencies, and Illustrative Quotes

\begin{tabular}{|c|c|}
\hline $\begin{array}{l}\text { Extracted Themes and \% of Students } \\
\text { Who Mentioned Theme in Focus Groups }\end{array}$ & Illustrative Quotes \\
\hline $\begin{array}{l}\text { Benefits from the Program } \\
\text { - Social skills }(66 \%) \\
\text { - Service learning ( } 56 \%) \\
\text { - Time/life management }(56 \%) \\
\text { - Perceiving oneself as a leader (56\%) } \\
\text { - Teamwork ( } 56 \%) \\
\text { - Understanding other perspectives } \\
\text { ( } 44 \%) \\
\text { - Value of supportive mentors ( } 44 \%) \\
\text { - Ethics development ( } 33 \%) \\
\text { - Logistics and planning experience } \\
\text { ( } 33 \%) \\
\text { - Cooperation between schools ( } 33 \%) \\
\text { - Understanding the importance of } \\
\text { communication ( } 22 \% \text { ) }\end{array}$ & $\begin{array}{l}\text { - "It teaches you social skills." - Student } 1 \\
\text { - "Yeah, because it is like real easy to see someone is hanging out with a specific group and label } \\
\text { them as just that, but when you really break it down and get to know them and work with them, it } \\
\text { really helps you realize that everyone is kind of the same but they are also kind of different." - } \\
\text { Student } 2 \\
\text { - "I have always found that working in groups was very difficult because I ended up doing it all, now } \\
\text { I feel like there is more equal sharing that needs to be done, and I appreciate that." - Student } 3 \\
\text { - "You gain life skills all throughout...and time management, too." - Student } 4 \\
\text { - "I think it kind of showed me that even though you are a kid or a teenager, because often times } \\
\text { you think that the adults should take care of that or I can't because I am a kid or a teenager, um, } \\
\text { it kind of showed you that kids and teenagers have huge impact." - Student } 5 \\
\text { - "Reading about the cosmopolitan ethic was pretty cool. It shows you that you are not all that } \\
\text { different and you should always be connected with other people. Um, race, differently or not, } \\
\text { whatever, you guys should always work together to become greater... that is kind of the sort of the } \\
\text { message I got from it." - Student } 6 \\
\text { - "...it teaches us just how key communication is to get everything to work together to fall into } \\
\text { place..." - Student } 7\end{array}$ \\
\hline
\end{tabular}


BLAST: A Service, Ethics, and Leadership Approach

Table 3: Focus Group Discussion Themes, Their Frequencies, and Illustrative Quotes (continued)

\begin{tabular}{|c|c|}
\hline $\begin{array}{l}\text { Extracted Themes and \% of Students } \\
\text { Who Mentioned Theme in Focus Groups }\end{array}$ & Illustrative Quotes \\
\hline $\begin{array}{l}\text { Negative Impacts on the Program } \\
\text { - Poorly structured meeting times (56\%) } \\
\text { - Effect of time spent on/in classes (33\%) }\end{array}$ & $\begin{array}{l}\text { - "I would like meetings that are set like on specific days." - Student 3"Grades, yes that is almost a } \\
\text { side effect, but this taught us life skills that we don't necessarily get in class." - Student } 7\end{array}$ \\
\hline $\begin{array}{l}\text { Improvements Suggested for the Program } \\
\text { - Improve awareness and recruitment } \\
\text { ( } 78 \%) \\
\text { - Improve program and meeting times } \\
\text { (56\%) } \\
\text { - Target more students }(56 \%) \\
\text { - Increase social events }(44 \%)\end{array}$ & $\begin{array}{l}\text { - "Yeah, making it more available to other people. I am sure a lot of other people want to be a part } \\
\text { - "I this but they weren't asked to join." - Student } 1 \\
\text { catch up." - Student } 8 \\
\text { - "The like junior high kids and younger ones are our future, so you have to kind of include those } \\
\text { kind of people in these kind of groups so they can input their ideas as well." - Student } 1 \\
\text { - "After that (the social event), I feel like we all really started to mesh together and we really } \\
\text { started to get to know each other and that really helped us out." - Student } 2\end{array}$ \\
\hline
\end{tabular}




\section{Conclusion}

The findings suggest that the BLAST model for rural youth development is a promising program that is helpful in developing service, ethical thinking, and leadership. The analysis demonstrated that the program had a meaningful impact on asset development among participants, particularly in:

- skill-building in the areas of teamwork, planning and life management, social interaction, and self-confidence;

- experience and confidence development in initiating service projects;

- ethical development; and

- social development.

The evaluation process also uncovered numerous areas of improvement to the model, such as changing meeting timing and scheduling, diversifying group demographics, improving recruitment, and having more social events.

This study contributes to the field of rural youth development in three ways. First, by integrating learning about service, ethics, and leadership, the model is an example of a specific, student-led, synergistic method that can lead to positive youth development. Though previous models have separately or dually employed service learning, leadership, and ethical development, the explicit combination of the three into a singular model is an innovative strategy that seems helpful. Second, despite being potentially applicable in both urban and rural settings, the program demonstrates its value within a rural Canadian community that shares characteristics with many other rural communities. This is especially important given the need for evidence about rural youth development. Third, the program was cost-efficient. With a cost of less than $\$ 100 C A D$, there is potential for the program to be scaled-up, even in the most resource-poor communities.

\section{Limitations and Areas for Further Research}

While the qualitative findings of this paper suggest that the program was successful in its attempt to promote service learning, ethical development, and leadership, the results of this paper are based on a single, small, specific cohort, and may not be generalizable to other populations. Repeating the program, and its evaluation, in this setting and in other rural and urban settings would be helpful, as would validating the qualitative theme identification with multiple researchers. 


\section{Acknowledgements}

We are grateful to all the students who participated in the BLAST program for helping pilot this model and contributing to its development. This research did not receive any specific grant from funding agencies in the public, commercial, or not-for-profit sectors.

\section{References}

Andresen, W., Dallapiazza, M., \& Calvert, M. (2013). Engaging young people as a community development strategy in the Wisconsin Northwoods. New Directions for Youth Development, 138, 125-140. Retrieved from: http://onlinelibrary.wiley.com/doi/10.1002/yd.20062/pdf

Catalano R.F., Berglund M.L., Ryan J.A.M., Lonczak H.S., Hawkins J.D. (2004). Positive youth development in the United States: Research findings on evaluations of positive youth development programs. The Annals of the American Academy of Political and Social Science, 591(1):98-124.

Devaney, E., O'Brien, M.U., Tavegia, M., \& Resnik, H. (2005). Promoting children's ethical development through social and emotional learning. New Directions for Youth Development, 108, 107-116. Retrieved from: https://www.ncbi.nlm.nih.gov/pubmed/16570881

Edelman, A., Gill, P., Comerford, K., Larson, M., \& Hare, R. (2004). Youth development \& youth leadership. National Collaborative on Workforce and Disability for Youth. Retrieved from: http://files.eric.ed.gov/fulltext/ED485711.pdf

Harvey, S., Kirk, D., \& O’Donovan, T.M. (2014). Sport education as a pedagogical application for ethical development in physical education and youth sport. Sport, Education and Society, 19(1), 41-62. Retrieved from: http://www.tandfonline.com/doi/pdf/10.1080/13573322.2011.624594?needAccess=true

Hastings, L.J., Barrett, L.A., Barbuto, J.E., \& Bell, L.C. (2011). Developing a paradigm model of youth leadership development and community engagement: a grounded theory. Journal of Agricultural Education, 52(1), 19-29. Retrieved from: http://www.jae-online.org/index.php/back-issues/172volume-52-number-1/1526-developing-a-paradigm-model-of-youth-leadership-development-andcommunity-engagement-a-grounded-theory

Henness, S.A., Ball, A.L., \& Moncheski, M. (2013). A community development approach to servicelearning: building social capital between rural youth and adults. New Directions for Youth Development, 138, 75-95. Retrieved from: http://onlinelibrary.wiley.com/doi/10.1002/yd.20059/abstract 
Journal of Youth Development | http://jyd.pitt.edu/ | Vol. 12 Issue 3 DOI 10.5195/jyd.2017.451

BLAST: A Service, Ethics, and Leadership Approach

Scales, P.C., Roehlkepartain, E.C., Wallace, T., Inselman, A., Stephenson, P., \& Rodriguez, M. (2015). Brief report: assessing youth well-being in global emergency settings: Early results from the Emergency Developmental Assets Profile. Journal of Adolescence 45, 98-102. Retrieved from: https://www.ncbi.nlm.nih.gov/pubmed/26426457

Search Institute. (2012). Developmental assets: A profile of your youth. Minneapolis, Minnesota: Search Institute. Retrieved from: http://www.search-institute.org/sites/default/files/a/A\%26B\%20Sample\%20Report\%202012.pdf

Zaff, J.F., Lerner, R.M., \& Richard, M. (2010). Service learning promotes positive youth development in high school. Phi Delta Kappan, 91(5), 21-23. Retrieved from: http://eaglerockschool.org/data/files/News/HomepageNews/k1002zaf.pdf 